\title{
Reimagining mission in the public square: Engaging hills and valleys in the African City of Tshwane
}

\begin{abstract}
Author:
Thinandavha D. Mashau ${ }^{1}$

Affiliation:

${ }^{1}$ Department of Christian Spirituality, Church History and Missiology, University of South Africa, South Africa

Note:

This article forms part of the special collection on 'Doing urban public theology in South Africa: Visions, approaches, themes and practices towards a new agenda' in HTS Teologiese Studies/Theological Studies Volume 70, Issue 3, 2014. The collection is the result of the project 'Urban Public Theology', which was initiated by the Institute for Urban Ministry but later expanded to include several academic departments and institutes at the University of Pretoria (UP) and University of South Africa (UNISA). The leading centres in this regard were the Centre for Contextual Ministry (UP) and the Research Institute for Theology and Religion (UNISA).
\end{abstract}

\section{Correspondence to:}

Thinandavha Mashau

Email:

mashatd@unisa.ac.za

Postal address:

PO Box 392, University of South Africa, Pretoria 0003 , South Africa

\section{Dates:}

Received: 26 June 2014

Accepted: 09 Aug. 2014

Published: 10 Nov 2014
This article seeks to map out the future of Christian mission in the city context. African cities like Tshwane are not only expanding, but also present the church with a new frontier that needs to be crossed without crossing geographical boundaries. This article indicates that life in the City of Tshwane is paradoxically placed. Whilst life in the valleys of Tshwane is like walking in the valley of the shadow of death, those on the high hills (the places of power) continue with their dominance and pretence as solution providers, whilst hiding the presence of those who are marginalised. This article proposes that the future of the Christian mission lies not only in identifying those powers, but also in engaging them in a transformative way so as to usher the justice and shalom of God into this highly contested space.

Each generation must discover its mission, fulfil it or betray it, in relative opacity. (Frantz Fanon, The wretched of the earth)

\section{Introduction}

The quest to reimagine mission in the public square is conducted not only within the same spirit of attempting to map out my personal niche area in academia, but also to spell out my vision and work as a mission practitioner on the streets and pavements of Tshwane. I am therefore unashamedly an African Missionary missiologist who is passionate about the city as my immediate laboratory in my personal journey of faith and as an academic. I move from a presupposition that says: 'The future of mission and missiology is in the city'. For me the city is a creative space, which is paradoxically placed. It is a contested space where the hills in it constantly change its landscape; the hills also use their powers to hide the valleys and streams therein. Therefore, my intention with this article is to demonstrate that the future of Christian mission in the public square, like the City of Tshwane, is in critical engagement with its hills and valleys with an eye to bringing God's shalom and justice to the marginalised city dwellers. My choice of the title is influenced by my reading of a liturgical piece of work by Professor J.N.J. (Klippies) Kritzinger. In his encounterological reading of Psalm 121 in the context of Tshwane, Kritzinger (2008a:337-338) creatively formulated a responsive liturgy for Melodi ya Tshwane congregation, as follows:

L: We lift up our eyes to the hills,

to the high places in and around Pretoria;

Where does our help come from?

Does our help come from Meintjieskop,

from the Union Buildings, centre of political power?

C: $\quad$ Our help comes from the LORD,

who made heaven and earth

L: $\quad$ Does our help come from Thaba Tshwane,

from the National Defence Force, centre of military power?

C: Our help comes from the LORD,

who made heaven and earth

L: Does our help come from Monumentkoppie, from the

Voortrekker Monument, reminder of the power of the past?

C: Our help comes from the LORD,

who made heaven and earth

L: $\quad$ Does our help come from the high building

of the Reserve Bank, centre of economic power?

C: Our help comes from the LORD,

who made heaven and earth

L: Does our help come from the high buildings of Unisa or the

University of Pretoria, centres of intellectual power?

C: Our help comes from the LORD,

who made heaven and earth

How to cite this article: Mashau, TD, 2014, 'Reimagining mission in the public square: Engaging hills and valleys in the African City of Tshwane', HTS Teologiese Studies/Theological Studies 70(3), Art. \#2774, 11 pages. http://dx.doi.org/10.4102/hts.v70i3.2774

Copyright: @ 2014. The Authors. Licensee: AOSIS OpenJournals. This work is licensed under the Creative Commons Attribution License. 
L: We lift up our eyes to the hills,

To the high places in and around Pretoria;

Where does our help come from?

C: Our help comes from the LORD,

who made heaven and earth;

who is the same yesterday, today and forever;

who remains faithful to his promises,

who never forsakes the work of his hands. Amen.

Whilst reading this responsive liturgy, the prophetic voice that accompanied its formulation intrigued me. It reminded me of how important the prophetic witness of the church is in imagining the transformational mission of the church in the public square. Furthermore, it reminded me of the significant role that the prophetic witness of the church played in bringing about the demise of apartheid; a matter which is well recorded in the writings of Van Wyk (2005), Kuperus (2011) and Kumalo (2013), amongst others. It also reminded me of the urgency of reclaiming the public square, both by mission practitioners and missiologists, in the light of: (1) the loss of credibility in providing prophetic witness by churches who either supported or were silent during the times of apartheid; (2) contradictory voices from churches, namely the emergence of the National Interfaith Council of South Africa (NICSA) which openly supports the Zuma administration and marginalisation of the South African Council of Churches by government in the process because of its critical stance (what Tinyiko Maluleke calls 'Prophetic witness in critical solidarity') (see Kumalo 2013:12); (3) the deafening silence of those churches that out of piety are suffering from what Boesak and De Young (2012) call 'Christian quietism' in their book entitled Radical reconciliation: beyond political and Christian quietism; (4) efforts by government and African National Congress (ANC) officials to silence the church, with the call for Archbishop Emeritus Desmond Tutu to stay away from politics by President Jacob Zuma being one such example; and (5) religious utterances by the ruling party which are a mockery and a slap in the face of the Christian faith. The book by Gareth van Onselen (2014), Clever blacks, Jesus and Nkandla: the real Jacob Zuma in his own words, is helpful in this discourse.

In reimagining mission in the public square, becoming a voice for the voiceless is not optional for Christian churches in a time such as this. In setting the tone and agenda for my future involvement as an academic and mission practitioner, this article seeks to focus on engaging the hills and valleys of Tshwane as something that requires urgent attention in our time. These high buildings not only have the ability to change the landscape of our city by hiding its valleys and hills; they also represent social and economic inequalities in South Africa, reminding us of the country's Gini coefficient (the most commonly used measure of inequality), which is the highest in the world. An example that can be used to illustrate this point is the squatters in Moreleta Park who are on the doorstep of the massive infrastructure of the Dutch Reformed Church Moreleta Park, the Woodhill Golf Estate and College, Mooikloof Estate and Woodlands Boulevard.
The question thus remains: how, then, can we reimagine Christian mission in the public square by engaging the hills and valleys of the City of Tshwane? In response, this article is structured as follows: (1) the introduction; (2) setting the tone by providing a missiological framework; (3) living and engaging the valleys of the City of Tshwane; (4) engaging the hills of Tshwane; (5) outlining a vision for doing mission and missiology in the City of Tshwane; and (6) the conclusion.

\section{Setting the tone: A missiological framework}

This study is undertaken from a Reformed missiological perspective with special emphasis on urban missions and theology. Whilst being conscious of other Christian traditions and practices, my personal journey of faith as an African Christian, missionary practitioner and academic has been formed and shaped by the Reformed faith (Calvinist tradition). My approach is informed by two negative realities about the Reformed faith in South Africa, namely (1) Calvinism is to blame for apartheid, on the one hand. The historical three sister churches, the Dutch Reformed Church (Nederduitse Gereformeerde Kerk), the Netherdutch Reformed Church of Africa (Nederduitsch Hervormde Kerk), and the Reformed Churches in South Africa (Gereformeerde Kerke in Suid-Afrika), directly or indirectly spearheaded and promoted apartheid. This is accounted for in many writings (Kuperus 2011; Van Wyk 2005, amongst others). On the other hand, (2) this tradition is rich in terms of a theoretical framework for its missionary ecclesiology, even though its practice is deficient. Speaking to the American context, which is also applicable in the South African context, John Miller (1997) captures this view as follows:
... the Reformed community, along with the broader evangelical church, has lost much of the impact it had on the world in other periods since the Reformation. It seems as if we are heirs to a vast spiritual inheritance, but we don't know what to do with it. We know it is valuable, so we guard it to keep it intact. But we lack the practical wisdom to take our fortune and reinvest it, so that the treasures of the past may yield new bounty in our generation. (p. 10)

Methodologically, I am consciously influenced by the praxis matrix proposed by Klippies Kritzinger, although I use a more general method of contextual theological reflection. In his article, 'Mission as prophetic dialogue', Klippies Kritzinger defines his praxis matrix as 'A missiological approach that discerns contextual priorities [and] consciously integrates the theology and practice of mission' (Kritzinger 2013:37). It is from this perspective that he developed an understanding of 'missiology as encounterology' (Kritzinger 2008b). I applied this methodological framework to engage the hills and valleys of Tshwane, while at the same time developing a missiology from below; one that is formed and shaped where the rubber hits the road. Consequently, 'theology of the place', 'theology in the margins', 'pavement theology', 'theology of hope and accompaniment' are born and nurtured in a particular context like the City of Tshwane where I do mission and missiology. Following the encounterological reading of Psalm 121 by 
Kritzinger, I use the metaphors of 'valley of the shadow of death' (Ps 23:4) and 'hills' (in Ps 121) imaginatively to depict the reality of life in the African City of Tshwane.

Mission in this article is defined as critical prophetic witness in transformative encounters that seek to bring the justice and shalom of the reign of God to the city. This definition demonstrates that city missions call for an approach which transcends the notion of mission as evangelism or conversion of souls; hence David Bosch (1991:551) would have called for 'transforming mission'. Transforming mission, as understood by David Bosch, is like a double-edged sword, one that seeks to 'transform reality' and at the same time 'be transformed' by that reality (Bosch 1991:511).

My interlocutors in this article are: (1) encounterological reading of Psalms 23 and 121, and Isaiah 40:1-5; (2) engagement with fellow academics (in the field of theology and politics) in the form of a literature review; (3) engagement with those in the valleys of Tshwane through my involvement at New Life City Church (as a mission practitioner), the Centre for Reformational Urban Ministry in Africa (CRUMA), and the Meal of Peace community engagement project of the Department of Christian Spirituality, Church History and Missiology at the University of South Africa (UNISA) (a project which works with the homeless in collaboration with the Tshwane Leadership Foundation); and (4) the principalities and powers that be in the City of Tshwane. My approach is one of providing a critical prophetic witness in bold humility. I agree with Kritzinger in this instance that we cannot afford a 'Christ-against-culture' approach. Accordingly:

City dwellers are forced to deal with these powers on a daily basis, and need to learn how to use them responsibly and engage them prophetically (when necessary), as they work for the coming of God's reign of justice, peace and joy. (Kritzinger 2008a:338)

This brings us to the point where we need to reimagine mission in the public square.

\section{Reimagining mission in the public square}

In setting the tone for reimagining mission in the public square in a time such as this, Andrew Kirk noted, in the same spirit as the popular dictum by Frantz Fanon, that each new generation of Christians may have to tackle issues not faced or adequately addressed by previous ones (Kirk 1999:14). When studying the history of the Christian mission and the development of its theology over the years, it is clear that this assumption is true. For instance (1) the question 'How missions?' was debated at the Edinburgh Conference (1910); (2) the question 'Wherefore missions?' was debated in 1928 at the Jerusalem Conference (it was at this meeting where secularism and syncretism were seen as the two major threats to Christian missions); (3) the question 'Whence missions?' was debated in 1938 at the conference held in Tambaran (the key issue dealt with here concerned mainly the relationship and approach of Christianity to nonChristian religions); (4) the question 'Whither missions?' was debated in 1947 at Whitby (the Christian mission at Whitby was defined in terms of evangelism and was seen by members of an indigenous world church as 'Partners in Obedience'); and (5) the question 'Why missions?' was dealt with at the conference at Willingen in 1952. The discussions at this conference considered the theological presuppositions for missions at a deeper level and within a broader context, but never reached consensus on the missionary obligation of the church; the question 'What is the Christian mission?' was dealt with in 195-1958 at the Ghana Assembly. This last question should be asked even today. The ambiguity as to how the concept should be understood and applied continues in Africa and elsewhere in the world. Musimbi Kanyoro (n.d) captures this as follows:

I often think that we in Africa have misunderstood our call to mission. The word mission itself raises certain ambiguities in our understanding. Mention mission and missionaries and you think of all the foreign brothers and sisters who live in our villages working in hospitals, translating our Bibles and teaching women hygiene and sewing. They bring themselves and the money that runs our churches. We therefore often understand mission as receiving something rather than giving. We also often think mission is only possible when it involves movement to other places, and witness to people other than one's own. Thus mission among ourselves and for ourselves is not an issue that keeps us awake with concern.

In my quest to attempt to clarify this ambiguity and in reimagining Christian mission in an African city like Tshwane, I have come to conclude that missional, urban, public, virtual and educational should be the missiological guidelines that underpin the engagement with the hills and valleys of Tshwane.

\section{Going missional}

Linguistically, the term missional is an adjective form of the noun mission. The word missionary can be used interchangeably with the word missional (Wright 2006:22), but the latter is preferable, seeing that it provides fresh access to the missionary enterprise and promises a breakthrough in terms of unlocking the minds of many to embrace what God is doing in the world in terms of his mission to save and transform humanity (missio Dei). The use of the word missional presupposes a radical shift in terms of what churches are doing and should do (missiones ecclesiae) as they participate in the mission of God. It also suggests a radical shift in terms of our understanding of what the church is. Missional churches are presumed to be different from churches which are considered mission-minded. Churches which are missionminded are churches which: (1) are sensitive and considerate in as far as the agenda of mission is concerned, but still treat it as a peripheral activity of the church; (2) they normally collect money, pray for a missionary abroad, and expect reports from time to time so that they can continue to raise more funds for the missionary (foreign mission); (3) some of these churches always look for opportunities to appease their conscience for not taking matters of mission seriously by 
engaging in what we call chequebook mission; and (4) some of these churches will have what we call mission commissions in their midst - and encourage the spirit of engaging in one or many mission projects.

Going missional is a different story all together. In his book, Missional Renaissance: Changing the scorecard for the Church, Reggie McNeal (2009:xvi) points out that it requires from a person to make three shifts, both in their thinking and in their behaviour: (1) from internal to external in terms of ministry focus; (2) from programme development to people development in terms of core activity; and (3) from churchbased to kingdom-based in terms of leadership agenda. These shifts, according to McNeal (2009:xvi), are the signature characteristics of what missional means. They move an individual to define church and to do church differently.

A missional church seeks to encourage all members of the church (evangelists, educators, counsellors, environmentalists, business people, and advocates for social transformation in urban spaces, amongst others) to serve in all forms of mission engagement where God has called and placed them in this life. This is in line with the Reformed worldview; one that seeks to acknowledge the Lordship of Christ in all spheres of life. Actually, it was the famous Dutch statesman and theologian, Abraham Kuyper, who said: '... there is no square inch in the whole domain of our human existence over which Christ, who is Sovereign over all, does not cry: "Mine!"' (Harink 2002). Mission thus becomes the DNA of every Christian, thereby reclaiming space for the office of believer in all institutional churches. You are therefore busy with mission when you are preparing dinner for your family, assisting your children with their homework, or ministering to your colleagues at work who need a word of advice or ask for counselling. You are busy with mission when you speak on behalf of the voiceless and the marginalised in society. And yes, you are busy with mission when you are taking care of God's creation. In essence, the church of God is busy with mission when we become the hands and feet of Christ in advancing his reign here on earth.

\section{Going urban}

The future of Christian mission (and by implication missiology - if it is a living academic discipline) is in the city. The importance and urgency of going urban is captured by two urban missionary missiologists, Roger Greenway and Derrick Mashau, as follows: 'Rather world cities without a church than a city with a disobedient church - a church without a vision for urban missions' (Greenway \& Mashau 2007:1). Imagine! Imagine a city with a church, but one that does not take seriously its missional calling. Imagine a church that does not take seriously its calling to engage urban principalities and powers that harm or destroy people's lives; such a church will never make any serious inroads in terms of impacting and transforming the community that it serves.

Urban explosion (Verster 2000:16) in Africa presents the church with a new frontier for missions (Greenway \& Mashau
2007:8). Part of my thesis in this article is that the future of the Christian mission is therefore in the city. Christian churches are now able to reach out to the vast conglomeration of people in our cities, thereby reaching the world without crossing any geographical boundary.

Going missional requires a critical and innovative understanding of the nature of space a city like Tshwane presents, namely: (1) it is a creative space requiring innovation and creativity in our approach to mission as well (De Beer [2008:183] calls this 'imaginative alternatives'); (2) it is a contested space where issues of power and justice will always constitute the agenda of the Christian mission. Contestation in the city context is captured and explained vividly by De Beer (2008) as follows:

Inner-city is permanently contested. There is a battle between local authorities, private developers, slum landlords, civic organisations, resident groups, landless groups, informal traders, drug pushers, and drug users all wanting to appropriate inner-city space for their own purposes. (pp. 183-184)

It is (3) a space of exclusion where the homeless, sex workers, foreigners, street vendors and many others who are on the margins are excluded from the mainstream economy and socio-political landscape of our city. Most of them scramble for crumbs just like Lazarus. According to De Beer (De Beer 2008:182), 'Forces that cause exclusion globally also cause social, economic or cultural exclusion locally'; (4) it is a war zone space where there are both physical and spiritual casualties. According to De Beer (De Beer 2008:193), 'Urban spatial and economic exclusions lead to social, emotional, economic and even physical death'. Grigg (1992:162), on the other hand, speaks of 'power encounter' to refer to spiritual warfare in the city; and (5) it is a space of alternatives.

Driven by the spirit of consumerism, city dwellers are confronted with alternatives to almost everything - socially, politically, economically and religiously. That is why, on a spiritual front, city dwellers hop from one church to another - shopping around for what is best for them; as such they often prefer to be free riders in any institutional church, rather than disciples. Their choices are diverse and varied, namely: (1) African Initiated Churches occupying open spaces for worship in the city; (2) independent Pentecostal groups gathering in shopfronts, museums and school halls; (3) traditional mainline churches; (4) suburban churches; (5) township and informal settlement churches; (6) megachurches; and (7) the emerging e-church movement of those who are going virtual and viral (De Beer 2012:258-259).

Going urban is exciting and challenging. If we are to reimagine mission in this context, De Beer (2008) suggests the following (which I find profound):

\footnotetext{
As we become present enough to be confronted by this, we first have to confront death in our hearts - the death of our ignorance; our apathy; our intellectual captivity; the death of our own inability to transcend the hopeless reality around us with clear vision; the death of fatigue as we engage in the contest ourselves. But we also need to allow the voices of death to confront the Church and its captivity, the Church and its complacency in the face of contestation. (p. 193)
} 
The church should do so prayerfully. This is one reason why urban missiologists like Roger Greenway will consistently, in their interpretation of Jeremiah 29:7, call on Christians who intentionally occupy urban spaces to seek its shalom and its prosperity (Greenway 2007:42). Where the city prospers, it also prospers Christian mission in such a context. Mission and missiology should therefore serve as God's agents of transformation in urban spaces.

\section{Going public}

The call to engage in public theology in postcolonial and post-apartheid South Africa is receiving serious attention through scholars who participate in the Beyers Naudé Centre for Public Theology at the University of Stellenbosch and the Centres for Public Theology and Contextual Ministry at the University of Pretoria (UP). The scholarly works of Andries van Aarde (2008), Cobus van Wyngaard (2011), Vuyani Vellem (2013) and Piet Naudé (2014), amongst others, were born out of their efforts to develop and shape a public theology that seriously engages the public. These voices are building on 'a rich history of engaging state and society on a variety of issues' (Bentley n.d.).

In this article, the call to go public is one that seeks to name and critically engage the principalities and powers (the powers that be) in the City of Tshwane. In my personal journey of faith, both as a pastor and as an academic, it has become clear that churches and institutions of higher learning can become powers that are oppressive of the people who they seek to serve. I learned in the process to speak out, only to find out that the powers that be will always try their best to silence and even marginalise you. I could not be silenced because of my Reformed faith. I share the same conviction with Vuyani Vellem who unashamedly demonstrated in his article 'The Reformed tradition as public theology' that the Reformed faith is intrinsically public (Vellem 2013:1).

The call in this article to engage the hills and valleys of Tshwane is similar to the one made by Nico Botha in his article 'Living at the edge of empire: Can Christianity prevail and be effective? A theological response to the historical struggle between empire and Christianity' (Botha 2011). In defining the place of missiology in the postcolonial era, Reggie Nel (2011:157-170) critically calls on the church to engage the 'spirit of domination' and the 'empire' in his article entitled 'Postcolonial missiology in the face of empire in dialogue with Frantz Fanon and Steve Bantu Biko'. The call to engage critically the powers that be in a public space, like the City of Tshwane, is therefore not unique. Kritzinger (2008a:337-338) identified some of the principalities and powers in the City of Tshwane; as I build on that foundation, my focus is to critically engage some of them with an eye to mapping out the future of Christian mission in the public square.

\section{Going virtual and viral}

The world is becoming virtual and viral. The Arab Spring was sparked and fuelled by a video that went viral shortly after being uploaded (Bruns, Highfield \& Burgess 2013:871), while a twerking video of young women dancing provocatively at a graveside in Atteridgeville stirred up heated debates in South Africa. In education, digital libraries and online journals are the talk of the hour. Even in the African context where access to technology is limited, virtual learning is imperative for Open Distance Learning (ODL). This technological revolution affects the whole of life, including religious and spiritual activities. In a world where Christianity is often met with indifference and hostility, the use of technology can unlock these barriers. Speaking of the Chinese context where Christianity is met with fierce opposition, this is what Enoch Kim (2010) had to say:

In creative access nations, where there are limitations to open evangelism and discipleship, building virtual communities seems to be an appropriate supplementary tool to help local churches with this need. Of course, there is intervention and checking from a higher realm in the Internet world. Christian Internet activity could also easily become suppressed or strictly regulated. However, from my surveys, I was astonished to discover that healthy Christian online networks are actively running today in China. (p. 183)

The mission of the church should therefore enter cyberspace and make use of social media tools, such as Twitter, Facebook, WhatsApp, blogging, and so on. Going virtual gives the church access to reach out and engage those living in the valleys and on the hills of Tshwane. Our cultural understanding of the church coming together under one roof is challenged to the core with the emergence of online churches where people worship in their own homes by using a radio or a computer screen. Healing ministry is also received online with the socalled 'touch the screen and receive' culture. This calls for serious missiological engagement inside and outside the church confines. Going virtual and viral can help to advance the kingdom of God and transform our communities. The use of Facebook and blogging at New Life City Church (NLCC) (where I am involved as a mission practitioner and researcher who uses NLCC as my laboratory) is proving effective in terms of creating awareness and visibility and impacting lives through the sharing of gospel verses, short messages and Bible study notes. The feedback has always been positive. Virtual membership is also possible to those who literally cannot access the institutional church. Such members can be allowed space to receive sacraments at the instruction of the officiating pastors. This sounds like a radical shift from our traditional way of doing church; indeed going virtual will require a totally new paradigm in terms of how we think and do church and mission.

\section{Going educational}

An urban explosion in the African City of Tshwane not only presents a new frontier for Christian mission, it also presents a huge challenge that affects theological training. Training of church planters and urban workers in different fields like counselling, children and youth ministry, church planting and revitalisation is the need of the hour. A group like the Institute for Urban Ministry in our city was born out of this need, amongst other factors. I have witnessed within my 
own church denomination, the Reformed Churches in South Africa, a raging wave of planting more and more multiethnic (and/or multicultural) churches in the city context; in 2008 this led to the formation of the CRUMA to facilitate training to this end.

More and more storefront churches, which are independent and more prone to the 'fire syndrome' of being and doing church, are mushrooming in areas like Sunnyside (Pretoria) as never before. The outskirts of the City of Tshwane are also crowded with African Initiated Churches which congregate on a massive scale in strategic open fields. This development has seen an emergence of 'pavement theologians' and 'mission practitioners' who undertake a journey of planting churches without any theological training. Theology, and in particular the learned in higher places (e.g. educational hills like UNISA and the UP), should accommodate this need of the hour in their curriculum formation. I contend therefore that the future of missiology is in the city when we take a conscious decision to walk side by side with those smaller institutions which are already providing training to urban workers on a smaller scale. De Beer (2012:251) is therefore correct to conclude that urban South Africa presents a wonderful opportunity for liberating theological education. This also changes the nature of ministerial training from elitism to embracing not only diverse forms of training and ministries, but also tent-making as a form of doing ministry in the city.

\section{Living and engaging the valleys of the shadow of death}

Where does our help come from? When walking through the urban valleys of the shadow of death, where does our help come from? The metaphor used is drawn from Psalm 23:4:

Even though I walk through the valley of the shadow of death, I will fear no evil, for you are with me; your rod and your staff, they comfort me.

This Psalm was written by someone with a vast experience of shepherding the flock, but also somebody who drew serious lessons of life from the same experience; the sheep entirely depended on the shepherd for providence and sustenance (leading them into green pastures and quiet waters in $\mathrm{v}$. 2), direction (guiding them in paths of righteousness in v. 3 ), and security (in v. 4). The issue of security speaks to the title of this article. When the cloud of death is hanging over one's life, fear grips one's heart. The experience of walking in the valleys of the shadow of death is one that was also experienced by the sojourners in Psalm 121. Walking through the valleys on their way to Jerusalem for religious festivals was sometimes lonely and exposed them to the danger of being robbed and killed.

We use the metaphor of the 'valleys of the shadow of death' in this article to refer to such areas as the inner city, suburbs, super-suburbs, townships, and slums (informal settlements) in the City of Tshwane. The face of urbanisation in the City of Tshwane is therefore varied and diverse; what is common about each one of them is that they all reflect life in the 'valleys of the shadow of death'. If we come to terms with this reality, we will take it as our responsibility to follow where the missionary God is taking us in terms of how we can respond to such a situation by reimagining mission. I therefore concur with Stephan de Beer's (2008) conclusion that:

Only once we acknowledge the death in our midst, and confront the numbness of our own souls can the Spirit start to breathe into us visions of something different. While we are numb, we cannot hear the creative Spirit. While we are in the mainstream, we miss out on the creativity of the margins (p. 193)

If we are to apply the metaphor of the 'valleys of the shadow of death' in Tshwane, the following serve as examples (not meant to be exhaustive, but reflective of life in the City of Tshwane): (1) walking on the pavements of Robert Sobukwe Street in Sunnyside will expose you to the vast conglomeration of nationalities who grace our city, but at the same time you are exposed to the high levels of poverty, xenophobia, violence and drug dealing. Sunnyside is part of the inner City of Tshwane where the sun never sets; it is full of life, but in some instances not for good. Life in this space is never dull and boring, with tenants carrying beds and their belongings on their heads towards the end and beginning of every month (Mashau 2013:15); (2) ladies of the night ply their trade in the streams of Tshwane like Francis Baard day and night. Some of these women are students from tertiary institutions in Tshwane who were pushed into prostitution because of poverty (lack of money to pay for their lodging, food and clothing during their studies); (3) the shooting of Reeva Steenkamp at the home of Oscar Pistorius in Silver Woods Country Estate; (4) crime and violence directed towards those in the suburbs and those hiding behind the security walls and gates in the supersuburbs; (5) informal settlements; (6) the homeless; (7) corruption in government institutions and the private sector; (8) twerking at gravesides in Atteridgeville and surrounding areas (the dead are no longer respected); and last, but not least, (9) violent service delivery protests in Mooiplaats and Bronkhorstspruit, amongst others, point at the 'voicelessness and marginalisation of the public' (Nembambula 2014:150). It is also a sign that 20 years into democracy, the scars of colonialism and apartheid are yet to heal. The question that remains is whether we should continue to blame apartheid for the current failures, or not. Is there hope for our people in these valleys or have we reached a tipping point where our valleys are full of dry bones, as in Ezekiel 37?

Contrary to the good story which the ANC-led government tells (as part of its election campaigns), the unholy alliance of poverty, unemployment and inequality is ravaging our country at a rate that only God is able to salvage. The health system is in disarray with only those who can afford private medical aid schemes receiving the best service in private hospitals - served by caregivers who cannot afford to be treated in these hospitals or clinics. We can conclude therefore that life for city dwellers in Tshwane resembles 'the valley of the shadow of death' of Psalm 23 and to some extent the dry bones in Ezekiel 37. Help is needed, and it is needed 
urgently. But for some of these people, they turn to the hills and high places of Tshwane for help, instead of turning to God. This brings us to an engagement with selected hills of the African City of Tshwane.

\section{Engaging the hills of the African City of Tshwane \\ The Union Buildings}

We lift up our eyes to the hills, to the high places in and around Pretoria; Where does our help come from? Does our help come from Meintjieskop, from the Union Buildings, centre of political power? (Kritzinger 2008a:337)

The Union Buildings is the official seat of the South African government and is built at the highest point of South Africa's capital city, Pretoria. As a political powerhouse of South Africa, the sitting president remains the face of the Union Buildings and our people continue to look up to it for help. Can the Union Buildings come to our rescue?

Although South Africa has accomplished much in the span of 20 years of democracy, the country still have a long way to go in terms of turning the tide against poverty, unemployment and inequality. The severity of these challenges is further exacerbated by the high levels of fraud and corruption in both the public and private sector. The current administration under President Jacob Zuma never runs short of controversy, with the President at the forefront. This is captured in the following words: 'If anything, Jacob Zuma's greatest contribution to South Africa's democracy has been a series of debates that have forced us to examine the contradictions that run through our society' (Van Onselen 2014:xx). Perhaps missiology needs to examine the slopes that separate the tops of the hills from the bottoms of the valleys so that it can inform and inspire mission precisely on those slippery slopes. Whilst the presidency is at pains to explain away Guptagate and Nkandlagate, levels of unemployment (especially among the youth) continue to soar with the latest statistics of 2014 indicating that the overall unemployment rate stands at $25.2 \%$ for the first quarter of the year in a country with a population of some 51.8 million. The Zuma administration has also been hit by service delivery protests countrywide, with the City of Tshwane having its fair share of these. Whilst the government is credited for achievements in certain areas, such as housing and the allocation of social grants to more than 16 million citizens, it is clear that South Africans cannot look up to it to provide all the solutions to their plight in all areas of life.

\section{The Mandela Statue at the Union Buildings}

Where does our help come from? Does our help come from the Mandela Statue at the Union Buildings? Nelson Mandela, as the first democratically-elected president of South Africa, managed to mobilise South Africans to embrace the vision of a rainbow nation and nation-building which encapsulated the spirit of reconciliation in the country. His ability to inspire and motivate the nation to give its best, especially in different types of sport, brought forth a phenomenon that came to be known as Madiba magic. The ANC and the Zuma administration have often appealed to the legacy of Mandela in order to convince the nation to continue voting for them. In his 2010 State of the Nation address in Parliament, President Zuma encouraged all citizens to celebrate the legacy of Mandela by contributing towards nation-building. When Mandela became ill and it was clear that he was not going to recover, many South Africans sounded a warning about racial and xenophobic attacks. After his death, and when he was lying in state at the Union Buildings from 11 to 13 December 2013, the Madiba magic once again showed its power when the whole nation united to bid him farewell. When the mortal remains of Mandela were buried at Qunu on 15 December 2013 one would have thought that it was over with his vision, but the ANC-led government strategically resurrected him with the unveiling of a $9 \mathrm{~m}$ tall statue at the Union Buildings the following day. The Mandela Statue at the Union Buildings stands as a symbolic reminder to South Africans of his contribution towards national unity and reconciliation. Whilst Psalm 146:3 warns us not to put our 'trust in princes', have South African not perhaps done that in relation to Madiba? How can we allow him to continue inspiring us, without us 'putting our trust' in him?

\section{Thaba Tshwane}

Where does our help come from? Does our help come from Thaba Tshwane, 'from the National Defence Force, centre of military power?' (Kritzinger 2008a:337). Ordinarily, citizens of any given country should look up to its troops to provide defence, but can we as South Africans trust the South African Defence Force (SANDF) with our lives? Can we sleep peacefully, knowing that we are safe in their hands? In my critical engagement with Thaba Tshwane it became increasingly clear that as much as they are able to provide security for the country, they cannot be wholly trusted. There are three examples that I would like to cite to illustrate this point, namely: (1) the South African National Defence Union (SANDU) led its members (who are members of the SANDF) in staging a march to the Union Buildings to raise their grievances against the Zuma administration. This march led to violent confrontations with members of the South African Police Service (SAPS) who dispersed the meeting by using rubber bullets and teargas; (2) a scheduled meeting wherein Julius Malema addressed members of the SANDF at Lenasia on 12 September 2012. How constitutional was such a meeting? Was this meeting not contravening military protocol? Is Malema guilty of sedition? ${ }^{1}$; and (3) Guptagate, which saw a plane, organised by the wealthy Gupta family and carrying their family members and friends to attend a wedding in Sun City, landing at one of the National Key Points. This raised serious questions about the security of South Africa: are we really safe in the hands of the SANDF? This was further exacerbated by the alleged involvement of President Zuma. Surely our help cannot come from such a structure, no matter how mighty it might seem to be. It has

1.In his blog post of 12 September 2012 Pierre de Vos asked this critical question. 
its own shortcomings and weaknesses that render it helpless at times. That is why the SANDF requires men and women of the cloth to provide spiritual support as chaplains. It shows that they are mere mortals who also need God in their lives. Our soldiers fallen in the line of peacekeeping in Africa, which makes South Africa look like a superpower in Africa, in the same way as America to the rest of the world, is also a sign that the SANDF is not invincible. We salute their bravery in keeping peace, but they (together with all South Africans) are vulnerable and need help from God as well.

\section{The Reserve Bank}

Where does our help come from? 'Does our help come from the high building of the Reserve Bank, centre of economic power' (Kritzinger 2008a:338). When the global economic recession wreaked economic havoc, a great number of people lost their jobs, houses and cars because they could no longer afford to service their debts. South Africans however continued to look to the Reserve Bank, especially regarding the adjustment of the repo rate. Missiology has serious work to do in reflecting on economic systems and their role in deepening the valleys of suffering and lifting the hills of privilege in Tshwane. In his book, Capital in the 21st century, French economist Thomas Piketty (2014) underlines the role of the capitalist economic system in creating inequality. The work of Sampie Terreblanche (2002), especially his book $A$ history of inequality in South Africa, 1652 to 2002, conclusively points out how capitalism is enriching the rich at the expense of the poor. It is obvious that we cannot look up to the Reserve Bank, especially in an era where the capitalist system is managing to keep the marginalised on the margins. We have in the City of Tshwane many landless homeowners who are being milked by the capitalist system and at the same time cannot with any certainty claim to be homeowners until they service their mortgages in full.

\section{The North Gauteng High Court}

Where does our help come from? Does our help come from the North Gauteng High Court, powerhouse of our judicial system? It is 20 years into democracy, but the judicial system of this country is still perceived to be skewed. A question as to whether our judicial system can be of help to ordinary citizens of this country, who are poor, remains a bone of contention. A high profile case which has been dubbed 'the trial of the century', the trial of Oscar Pistorius, can serve as a point of reference to illustrate the severity of this matter. The double-amputee Olympian is standing trial for shooting and killing his girlfriend, Reeva Steenkamp, with his double tap ${ }^{2}$ shots receiving extensive media attention. In the first instance this trial is receiving international media coverage on a larger scale than any trial has ever received before. It is asserted that ' $[t]$ he trial has captured the world's attention on a level only comparable with the OJ Simpson trial 19 years ago' (Pillay 2014). Whilst this might be celebrated for placing the City of Tshwane and the country's judicial system on the global map, we should as a country be worried about the kind of media attention Pistorius is getting, compared to other murder charges of ordinary South Africans, as in the case of Anene Booysen. She was a 17-year-old girl from Bredasdorp in the Western Cape who was brutally gang-raped on 01 February 2013 and died in hospital the following day. With this in mind, what if 'I put it to you' ${ }^{3 \prime}$ (NDTV Sports 2014) that Pistorius's double tap shooting reminds us of the double standards applied when it comes to the rich and the poor in the eyes of the law. The rich and famous receive preferential treatment, whilst the poor and the little-known receive no attention. Therefore, the church in mission needs to engage the powers that be within the judicial system to demand equality for all within the eyes of the law. We need to stand up and be the voice of the voiceless who cannot afford justice due to the cost of lawyers who are only available to the rich. Justice is therefore a key dimension of Christian mission.

As much as Pistorius is innocent until found guilty by a court of law, his case opens another can of worms regarding gender-based violence. This violence is perpetuated against women and children, in particular. In a society where the majority of women who are murdered are killed in their homes by men who know them well and are supposed to protect them, missiology needs to reflect seriously on the causes of domestic violence and how best men, women and children can be empowered to overcome this scourge.

\section{Menlyn Mall}

Where does our help come from? Does our help come from Menlyn Park Shopping Centre, the largest urban mall in Tshwane? Menlyn Mall epitomes modern idolatry among those who worship at this great temple of consumerism worshipping at the service of the gospel of enrichment. True worship in the presence of God is highly contested in the city context where people prefer to replace God with sport, finance, leisure and more which are sited at God's rightful place in our lives (Mashau 2013:22). Claassen (2008) concurs as follows:

Everyone who is willing to sacrifice has first to build an altar. In order to find your altar of worship, just follow the trail of how you use your time, energy, money, affections. To whom or what do you offer your allegiance? At the end of the trail you will find what it is that you worship. The more time you spend before that throne, the more your life will reflect what or whom you worship. It is abundantly clear that our actions speak louder than words. (p. 13)

Worshipping at a shopping centre like Menlyn is further exacerbated by the spirit of consumerism; hence, the global church is also adopting marketing strategies used by secular business. This has prompted Ben de Klerk (2012:42) to conclude that: 'The first and dominating feature of this global monoculture is its consumerist character.' Advertising campaigns to sell products are blatant forms of evangelism: secularising mission, persuading people that they need ever more and better gadgets, clothes, food, cars and homes (go

3.This is a famous line (that has become a famous meme) by Gerrie 'the Bulldog' Nel. 
higher up the hills) in a city with deep valleys of poverty and deprivation. Missiology needs to reflect on ways to counter this mission of selfishness and greed, deeply infected by the so-called 'affluenza' virus. The book, Affluenza: The all-consuming epidemic defines it as 'a painful, contagious, socially-transmitted condition of overload, debt, anxiety, and waste resulting from the dogged pursuit of more' (De Graaf, Wann \& Naylor 2001:2).

\section{Institutions of higher learning}

We lift our eyes to 'the high buildings of Unisa' and 'the University of Pretoria, centres of intellectual power'. Where does our help come from (Kritzinger 2008a:338). Can excluded city dwellers, like the homeless of Tshwane, find help at these institutions? Are these institutions of higher learning providing answers or ministering to their felt needs? The 'distance' in the 'Open Distance Learning' nature of UNISA is bridging the gap of 'distance' in terms of access to education. The UP is also playing its part in terms of engaging in Public Theology in the city context through the two centres mentioned above. These two institutions of higher learning also play their part in terms of community engagement projects. The Meal of Peace project of UNISA in collaboration with TLF is one such project that shows that the University is hands-on. Whilst applauding these institutions for their good work, they cannot provide all the solutions for those in the valleys of our city. These institutions are also tainted by the capitalist system and the commercialisation of knowledge.

There are two areas of concern in terms of the influence of capitalism in institutions of higher learning: (1) what influences institutions of higher learning to start prioritising issues of community engagement of late? Is it a genuine concern to minister to the needs of the people whom we are working with or is it influenced by the envisaged research output? Are we not suffering from the so-called publish or perish syndrome? Are we doing enough for communities?; (2) there is no doubt that institutions of higher learning are, in the process of continued restructuring and recurriculation, also probing the question of the need for the continued existence of Theology (Missiology as a field of study that is perceived to be dealing with Christian evangelism and conversion is at the receiving end) in statefunded institutions. Is this not influenced by the economics of the dwindling numbers of those who enrol for Theology, especially at undergraduate level? The question of what is 'public' about missiology in the public square is therefore inevitable. Whilst this article does not allow space to probe further the issue on the continued marginalisation of mission and missiology in the church and institutions of higher learning (public universities in particular), this matter is well recorded. I deal with this matter extensively in my article entitled 'A reformed perspective on taking mission and missiology to the heart of theological training' (Mashau 2012). In his ground-breaking work, Theological education in missionary perspective, David Bosch did not only lament the gradual disappearance of missions or missiology from the curriculum of one theological institution after another
(Bosch 1982:13), but also firmly entrenched the critical role that missiology plays within theology, as follows:

Missiology acts as a gadfly in the house of theology, creating unrest and resisting complacency, opposing every ecclesiastical impulse to self-preservation, every desire to stay what we are, every inclination to provincialism and parochialism, every fragmentation of humanity into regional or ideological blocs, every exploitation of some sectors of humanity by the powerful, every religious, ideological, or cultural imperialism, and every exultation of self-sufficiency of the individual over other people or over other parts of creation. (Bosch 1991:496)

This critical function that Missiology plays in academia is similar to the role that mission plays in society. The public nature of missiology therefore lies in critical engagement with the hills and valleys of Tshwane.

\section{Our help comes from God}

'We lift up our eyes to the hills, to the high places in and around Pretoria; Where does our help come from? Our help comes from the LORD, who made heaven and earth' (Kritzinger 2008a:338). Christian mission in the city context should therefore be guided by God's mission as we seek to participate in what God is already doing in world cities in bringing total transformation, justice and shalom. Mission in this context should remind us of the prophetic message of Isaiah 40:1-5 about God levelling the social contradictions when the exiles return. The text is explicit: 'Every valley shall be raised, every mountain and hill made low; the rough ground shall become level, the rugged places a plain' (Is 40:4). Mission in the hills and valleys of Tshwane is working with God as the great 'leveller' (justice-bringer) in society; hence the call to reimagine mission in the public square by engaging these hills and valleys.

If our help comes from God, how does God help us? To answer this question, I propose the following:

- There is a need for city churches to embrace the missional ecclesiology, one that seeks to serve the missio Dei; in the same breath missiology should help shape the biblical and theological foundation of this missional ecclesiology by clarifying the relevancy of the missio Dei paradigm in doing mission for an African city like Tshwane.

- If mission is serving the missio Dei, we can safely conclude that mission and consequently missiology will only become redundant at the eschaton. Peter Tuit is therefore correct in asserting that 'missions will come to an end only when the new heaven and the new earth with a new humanity is revealed' (Tuit 2006:134).

- If mission is missio Dei, then it is not the task of Christian mission to convert people, but God's task (see 1 Cor 3:7).

- Christian mission should be faithful in fulfilling its missionary calling in the city context, working as the 'eyes', 'ears', 'heart', 'hands' and 'feet' of Christ in ministering to the felt needs of city dwellers. Christian mission will therefore be seen as listening to the stories and walking side by side with those on the margins, thereby seeking to gain God's intervention for their life challenges together. Christians should become caring communities in the public square. 
- Christian mission should serve as agents of transformation by bringing God's shalom and justice into the city context as they intentionally engage the social ills and economic and political powers in the City of Tshwane. Providing shelter for the homeless, transferring skills to empower those on the margins to access jobs, collaborating with government and private institutions to fight poverty, joblessness and inequality, and advocacy can be cited as some of the practical things that churches can do in and with the community.

- God helps by prompting us to embrace a spirituality that is intrinsically transformative. The landscape of worship in the city context should therefore be transformed from being consumer-oriented to God-oriented. Our worship (singing, praying, preaching, sacraments, etc.), meditation, praying and fasting should constitute the spirituality for mission encompassing the spirit of transforming encounters. The prophetic voice will in this instance never be missing from our worship services; indeed, worship will become a way of life instead of a once-off event on Sunday.

\section{Emerging themes for missiological research and teaching}

Those who are in the academia should take up the challenge of 'researching mission encounters' (Kritzinger 2011:54) in engaging the hills and valleys of Tshwane. The following emerging themes should form part of further research and training in the field of Urban Missiology:

- The biblical and theological basis for the theology of place' with a particular reference to the city and God's agenda for it.

- The relevancy of missional theology for an African city like Tshwane.

- Public theology, public justice and God's justice in the city context.

- City missions and the implications for curriculum formation.

- City missions and spiritual and theological formation within theological training in the public square.

- What is it that missiology can learn from other disciplines and what is it that other disciplines can learn from missiology in the city setting?

- What role can institutions of higher learning like UNISA play in shaping missiological encounters in the public square?

- How does Christian mission partner and collaborate with other agents of transformation in the city context (including government, non-government and other religious agencies from religious formations other than Christianity)?

\section{Conclusion}

The hills of Tshwane continue to flourish and benefit from the systems of this world, whilst those on the margins continue to be excluded from participating in the mainstream. Christian mission, in such a context, as proposed in this article is to bring shalom and justice of the kingdom of God by engaging the hills and valleys of Tshwane. If mission practitioners and missiology remains true to this calling, then the future of mission and missiology in the public square is certain and bright. Mission and missiology will always be on the roads or pavements or sidewalks or margins, probing the hills and seeking God's help for those in the valleys of our African City of Tshwane.

\section{Acknowledgements Competing interests}

The author declares that he has no financial or personal relationship(s) that may have inappropriately influenced him in writing this article.

\section{References}

'Barry Roux: Oscar Pistorius murder trial goes viral', NDTV Sports, viewed 08 March 2014, from http://sports.ndtv.com/athletics/news/222405-oscar-pistoriusmurder-trial-lawyer-goes-viral

Bentley, W., n.d., Defining Christianity's 'prophetic witness' in the post-apartheid South African democracy, viewed 26 May 2014, from http://uir.unisa.ac.za/ bitstream/handle/10500/9981/Bentley_15.pdf?sequence

Boesak, A.A. \& De Young, C.P., 2012, Radical reconciliation: Beyond political pietism and Christian quietism, Orbis Books, Maryknoll.

Bosch, D.J., 1982, 'Theological education in missionary perspective', Missiology X(1), 13-33. http://dx.doi.org/10.1177/009182968201000102

Bosch, D.J., 1991, Transforming Mission: Paradigm shifts in theology of mission, Orbis, Maryknoll.

Botha, N.A., 2011, 'Living at the edge of empire: can Christianity prevail and be effective? A theological response to the historical struggle between empire and Christianity', Studia Historiae Ecclesiasticae 37(3) 133-155.

Bruns, A., Highfield, T. \& Burgess, J., 2013, 'The Arab Spring and Social Media Audiences: English and Arabic Twitter Users and Their Networks', America Behavioural Scientist 57(7), 871-898. http://dx.doi.org/10.1177/0002764213479374

Claassen, O., 2008, Lifesong: Bible-centred worship for the emerging generation, Christian Focus Publications, Geanies House.

De Beer, S., 2008, 'Contesting inner-city space: global trends, local exclusion/s and an alternative Christian spatial praxis', Missionalia 36(2/3), 181-207.

De Beer, S., 2012, 'Urban South Africa: An opportunity for liberating theological education', Missionalia 40(3), 251-277.

De Graaf, J., Wann, D. \& Naylor, T., 2001, Affluenza: The All-consuming epidemic, Berrett-Koehler Publishers, San Francisco.

De Klerk, B.J., 2012, Liturgical involvement in society, Potchefstroom Theological Publications, Potchefstroom.

De Vos, P., 2012, Is Julius Malema guilty of sedition?, viewed 04 May 2014, from http://constitutionallyspeaking.co.za/is-julius-malema-guilty-of-sedition

Du Preez, M., 2013, A Rumour of Spring: South Africa after 20 years of Democracy, Zebra Press, Cape Town.

Greenway, R.S., 2007, 'Jeremiah: Seeking the shalom of the city', in R.S. Greenway, \& T.D. Mashau (eds.), An eye that sees: Vision for urban mission, pp. 38-49, Thitshi Productions, Potchefstroom.

Greenway, R.S. \& Mashau, T.D., 2007, An eye that sees: Vision for urban mission, Thitshi Productions, Potchefstroom.

Grigg, V., 1992, 'Church of the Poor', in R.S. Greenway (ed.), Discipling the City: A comprehensive approach to urban mission, pp. 159-170, Baker, Grand Rapids.

Harink, G., 2002, 'A historian's comment on the use of Abraham Kuyper's idea of Sphere Sovereignty, Journal of Markets \& Morality 5(1), 277-284.

Kanyoro, M., n.d., 'Thinking Mission in Africa', viewed 09 June 2014, from http:// www.sedos.org/English/kanyoro.html

Kim, E.J., 2010, 'A new mission tool in creative access nations: Christian virtual community in China' International Journal of Frontier Missiology, OctoberDecember, 183.

Kirk, J.A., 1999, What is Mission? Theological explorations, Darton, Longman \& Todd, London.

Kritzinger, J.N.J., 2008a, 'Where does our help come from? Psalm 121 in Tshwane', Missionalia 36(2/3), 337-338.

Kritzinger, J.N.J., 2008b, 'Faith to faith - Missiology as encounterology', Verbum et Ecclesia 29(3), 764-790.

Kritzinger, J.N.J., 2011, “"Missions as ...." must we choose? A dialogue with Bosch, Bevans and Schroeder and Schreiter in the South African context', Missionalia 39(1/2), 32-59. 
Kritzinger, J.N.J., 2013, 'Mission in prophetic dialogue', Missiology: An International Review 41(1), viewed 14 May 2014, from http://mis.sagepub.com/ content/41/1/35

Kumalo, R.S., 2013, 'Facts and faction: The development of church and state relations in democratic South Africa from 1994-2012', Journal of Church and State. http:// dx.doi.org/10.1093/jcs/cst025

Kuperus, T., 2011, 'The political role and democratic contribution of churches in postApartheid South Africa, Journal of Church and State 53(2), 1-29. http://dx.doi. org $/ 10.1093 /$ jcs/csr030

Mashau, T.D., 2012, 'A reformed perspective on taking mission and missiology to the heart of theological training', In die Skriflig/In Luce Verbi 46(2), 1-8.

Mashau, T.D., 2013, Coming back to the heart of worship: The hour of true and acceptable worship in the African city, AcadSA Publishing, Panorama.

McNeal, R., 2009, Missional Renaissance: Changing the scorecard for the Church, Jossey-Bass, San Francisco.

Miller, C.J., 1997, Powerful evangelism for the powerless: A new, revised edition of evangelism and your church, P\&R Publishing, Phillipsburg.

Naudé, P.J., 2014, “Public theology" from within the church? A reflection on aspects of theology of W.D. Jonker (1929-2006) Verbum et Ecclesia 35(1), 8 pages. http://dx.doi.org/10.4102/ ve.v35i1.1136

Nel, R., 2011, 'Postcolonial missiology in the face of empire: in dialogue with Frantz Fanon and Steve Bantu Biko', Studia Historiae Ecclesiasticae 37(4), 157-170.

Nembambula, P., 2014, 'Violent service delivery protests in the governance of public participation in a democratic South Africa', Mediterranean Journal of Social Sciences 5(9), 148-151.
Piketty, T., 2014, Capital in the twenty-first century, Harvard University Press, Cambridge. Pillay, V., 2014, “'Celibrity' Pistorius gets an unfair advantage', Mail \& Guardian, viewed 08 April 2014, from http://mg.co.za/article/2014-03-03-celebrity-pistorius-getsan-unfair-advantage

Terreblanche, S.J., 2002, A history of inequality in South Africa, 1652 to 2002, University of Natal Press, Pietermaritzburg.

Tuit, P.C., 2006, 'The relationship between the great commission and world transformation: Outline for a reformed missiology', in A.C. Leder (ed.), For God so loved the world: Missiological reflection in honor of Roger S. Greenway, pp. 113-142, Essence Publishing, Canada.

Van Aarde, A., 2008, "What is "theology" in "public theology" and what is "public" about "public theology"?', HTS Teologiese Studies/Theological Studies 64(3), 1213-1234. http://dx.doi.org/10.4102/hts.v64i3.81

Van Onselen, G., 2014, Clever blacks, Jesus and Nkandla: The real Jacob Zuma in his own words, Jonathan Ball Publishers, Johannesburg.

Van Wyk, I.W.C., 2005, 'The political responsibility of the church: On the necessity and boundaries of the theory of the two kingdoms', HTS Teologiese Studies/ Theological Studies 61(3), 647-682. http://dx.doi.org/10.4102/hts.v61i3.457

Van Wyngaard, C., 2011, 'The public role of the Christian community in the work of David Bosch', Missionalia 39(1/2), 151-167.

Vellem, V.S., 2013, 'The Reformed tradition as public theology', HTS Teologiese Studies/ Theological Studies 69(1), 5 pages. http://dx.doi.org/10.4102/hts.v69i1.1371

Verster, P., 2000, Good news for the city in Africa: With reference to the Apartheid City', IMER, Pretoria.

Wright, C.J.W., 2006, The mission of God: Unlocking the Bible's grand narrative, IVP Academic, Downers Grove. 